\title{
The Confessing Church (Bekennende Kirche) in Western Pomerania in Light of the Activity of St. Mary's Parish in Koszalin (Köslin) and the Rev. Friedrich Onnasch (1881-1945)
}

\author{
Małgorzata Grzywacz (iD https://orcid.org/0000-0002-7306-6225 \\ Institute for Cultural Studies \\ Adam Mickiewicz University, Poznań \\ e-mail: grzywacz@amu.edu.pl
}

\begin{abstract}
The article deals with issues related to the history of the relations between churches as institutions, and their individual clergymen, and the Nazi state. The source referred to in this article is the intimate journal of Minister Friedrich Onnasch (1881-1945), the superintendent of the Koszalin Church District and parish priest of Saint Mary's Church in Koszalin, murdered by Soviet troops in Barlinek in February 1945. A document written on a regular basis, never published, is a detailed account (though coded, due to censorship), showing the experience of the clerical office in a time of totalitarian oppression. It shows the situation in the Evangelical Church after 1933 and the commitment of Minister Friedrich Onnasch and others, among them Dietrich Bonhoeffer (1906-1945), associated with Pomerania, in the movement of the Confessing Church. It explores the areas of Christian religion in its Evangelical topography, limited to the space of the former Prussian province of Pommern (Provinz Pommern) and Western Pomerania after 1945.
\end{abstract}

Keywords: Western Pomerania, Nazi movement, Confessing Church

Słowa kluczowe: Pomorze Zachodnie, ruch nazistowski, Kościół Wyznający

The Evangelical Church of the Augsburg Confession (Lutheran Church) in the Republic of Poland can be seen as a "steward and depositary" of an extensive historical legacy. Part of this is directly linked to events which took place seventy-five years ago. The end of the Second World War was the defining moment for the geographical shape of today's Polish state. As a result of decisions made in Potsdam and Yalta, an area of just over 100,000 $\mathrm{km}^{2}$ was incorporated into Poland in 1945 . The area was 
$70,000 \mathrm{~km}^{2}$ smaller than that of the Eastern Borderlands of pre-war Poland, left outside the country's eastern borders. ${ }^{1}$ The new state, created under the aegis of Joseph Stalin, shifted Poland westwards to incorporate areas of the former German Reich, which were very diverse in terms of population, ethnicity and economy. A complete exchange of population took place in Lower Silesia and Western Pomerania. Most of the Germans either fled the advancing Red Army or were forcefully displaced. The promotion of the idea of a return to the old pre-Slavic territories lost to the "Germanic element" became a narrative intended as a kind of political and cultural "binder" for the newly inhabited areas. A mental "recovery" was to contribute to the effective integration of these areas into the experience of the new inhabitants over both the short and the long term ${ }^{2}$ via the ultimate removal of the Germans and the eradication of their culture.

In the Polish lands we are therefore exploring a "moved space,"3 where change has involved, among others, transformations of the existing land and the acquired and inherited cultural landscape. The process of the new inhabitants settling in and taking possession of the land meant secularization of the area by various means, including removing traces of religious buildings, mostly Evangelical ones. ${ }^{4}$ This also involved decomposition of cemeteries of villages, towns and cities ${ }^{5}$ and destruction or elimination of the original function of objects. Books, for instance, were either burnt in tile stoves or trashed. ${ }^{6}$

The end of the existence of Pomerania after 1945 coincided with the dissolution of the structures of the Evangelical Church present in this territory. Historically and geographically divided into Hither Pomerania (Vorpommern) and Farther Pomerania (Hinterpommern), incorporated as Western Pomerania into the new Polish state, the area adopted the Reformation in its entirety in 1534. Until the end of World War II, Pomerania and its inhabitants were nearly exclusively members of the Evangelical Church. The population exchange in these areas transformed the region in every possible way. After 1945 the "sacred space of the world" was taken over by the Roman

${ }^{1}$ S. Wierzchosławski, Ludność Ziem Zachodnich i Pólnocnych w świetle Narodowego Spisu Powszechnego 2002, [in:] Ziemie Odzyskane. Ziemie Zachodnie i Pótnocne 1945-2005. 60 lat w granicach państwa polskiego, A. Sakson (ed.), Poznań 2006, pp. 79-80.

2 Z. Romanow, Kreowanie "polityki pamięci” na Pomorzu Zachodnim 1945-2000, Poznań 2002.

${ }^{3}$ See M. Czermińska, Poruszona przestrzeń (świadectwa wędrówek ludów po traktacie jattańskim), [in:] eadem, Autobiograficzny trójkąt. Świadectwo, wyznanie i wezwanie, Kraków 2000, pp. 159-176.

${ }^{4}$ S. Jankowiak, Ziemie Zachodnie i Pótnocne w stosunkach państwo - Kościół w Polsce w latach 1945-1956, [in:] Między integracja a komunizmem. Społeczeństwa i kościoły Europy Środkowej. Materiaty z międzynarodowej konferencji naukowej, Szczecin, 8-9 czerwca 2001 r., K. Kowalczyk, A. Kubaj, R. Wróblewski (eds.), Tuchów 2001, pp. 88-96.

${ }^{5}$ See T. Sławek, Akro/nekro/polis. Wyobrażenia miejskiej przestrzeni, [in:] Pisanie miasta-czytanie miasta, A. Zeidler-Janiszewska (ed.), Poznań 1997, pp. 29-31; Nekropolie Pomorza, J. Borzyszkowski (ed.), Gdańsk 2011.

${ }^{6}$ See K. Kuszyk, Poniemieckie, Wołowiec 2019.

7 This sacred space is a subspace of a geographical one and one of the fundamental research issues of the geography of religion. Out of respect for this research area, scholars call this section of geographical sciences "sacred geography". A. Jackowski, Święta przestrzeń świata. Podstawy geografii religii, Kraków 2003, p. 7. 
Catholic Church, ${ }^{8}$ paving its way, just like the state authorities, via direct references to the idea of "Regained Territories." This process meant, in a new political and social context, removing all traces of the former inhabitants of Western Pomerania belonging to the Evangelical Church. Over the next decades, German-speaking evangelicals almost completely disappeared from the religious map of these lands, ${ }^{9}$ yet some small prayer groups, operating quasi-illegally, remained in Szczecin, Słupsk, Koszalin, Białogard, Świdwin, Szczecinek, Wołcza Wielka, Gardna Wielka, Główczyce, and Rokity. ${ }^{10}$ In the meantime, the ethnic composition of Western Pomerania evolved further, ${ }^{11}$ it was only the collapse of communism in 1989 that contributed to a new stabilisation of the Lutheran Church in Poland ${ }^{12}$ and opened up further opportunities for discovering the extant traces of the history of the region. Today, Lutheran parishes in Szczecin, Koszalin, and Słupsk provide pastoral care to a group of about one hundred people whose Evangelical roots are connected with the German language; the number of congregation members is decreasing yearly. ${ }^{13}$

One important issue related to the pre-war history of the Evangelical ${ }^{14}$ Church in Pomerania,${ }^{15}$ highlighted in studies on religion in totalitarian systems, is the Confessing Church (Bekennende Kirche) and its conflict with the Nazi regime. The bestknown representative of this group within the Evangelical Church in the German Reich was Dietrich Bonhoeffer (1906-1945), the eminent theologian, minister, member of the resistance movement against Hitler's ideology, and martyr for the faith during the Nazi period. His underground activity in today's Pomerania is discussed by most works devoted to that period in the history of Nazism. ${ }^{16}$ However, he is not the only German to manage to counter the Nazi vision of the world and to be vividly remembered by today's residents of this region of Poland. One other person was the Rev. Friedrich Onnasch (1881-1945), ${ }^{17}$ the pastor of the Marian Parish in former Köslin,

${ }^{8}$ See Dzieje Kościoła rzymskokatolickiego na Pomorzu Zachodnim, vol. 1: 1945-1956, M. Siedziako, Z. Stanuch, ks. G. Wejman (eds.), Szczecin 2016.

${ }^{9}$ D. Matelski, Niemcy w Polsce w XX wieku, Warszawa-Poznań 1999, pp. 256-259.

10 J. Kłaczkow, Kościół Ewangelicko-Augsburski w Polsce w latach 1945-1989, [in:] idem (ed.), Kościoły luterańskie na ziemiach polskich (XVI-XX w), vol. 3: Wramach Rzeczpospolitej, państw ościennych i na emigracji, Toruń 2012, pp. 194-195.

${ }^{11}$ Poles were joined by Ukrainians, Greeks and Armenians. See Pomerania ethnica. Mniejszości narodowe na Pomorzu Zachodnim, M. Giedrojć, J. Mieszkowski (eds.), Szczecin 1998.

${ }^{12}$ In 2017 there were around 70,000 Lutherans in Poland. See 500 lat Reformacji w Polsce, online, http://www.stat.gov.pl, with the most up to date statistics [access: 20.06.2020].

${ }^{13}$ Data according to the information of pastors of the Evangelical Church of the Augsburg Confession in Poland as of the end of 2019.

${ }^{14}$ Evangelism is a collective name used to refer to the churches which emerged in the wake of the 16th-century Reformation. These are first of all the churches of the Lutheran and Reformed traditions and those which in later centuries developed through ecclesiastical union (Evangelical-Union), Religia. Encyklopedia PWN, T. Gadacz, B. Milerski (eds.), vol. 3, Warszawa 2001, pp. 486-487.

${ }^{15}$ See H. Heyden, Kirchengeschichte Pommerns, Stettin 1937.

${ }^{16}$ E.g. D.L. Bergen, Twisted Cross. The German Christian Movement in the Third Reich, Chapel Hill 1996. V. Barnett, For the Soul of the People. Protestant Protest Against Hitler, Oxford 1992.

${ }^{17}$ Friedrich Onnasch was born on 8 October 1881 in Studzieniec n. Chodzież, as the fifth of nine siblings. His father, also Friedrich (1839-1897), who came from Sambork near Jastrow, had a large farm which was sold after his death. His mother, Clara Onnasch née Dobberstein, on becoming a widow raised 
whose activity is commemorated by a plaque at 3 Matejki Street in Koszalin. This article presents the most important forms of activity of the Koszalin superintendent and his contribution to the Confessing Church.

\section{The Church in Pomerania and the Parish of St. Mary in Koszalin during the Weimar Republic}

After the end of World War I, changes in the functioning of the Evangelical Church took on a revolutionary character in Germany. The church newsletter, first issued in 1869 in Szczecin, changed part of its name in 1918, as the adjective "royal" 18 was replaced by "evangelical." This qualitative change reflected the status of the Church in the new political context. The collapse of the former way of governance had a direct impact on the functioning of the Protestant Churches. The close connection between the secular and ecclesiastical authorities, in existence since the sixteenth century and expressed in the term summus episcopus, with the ruler acting as the supreme bishop, the supreme authority controlling the local church in the areas subordinated to it, ceased to exist, also due to the abdication of William II. An Extraordinary Provincial Synod convened in March 1919 and its decisions showed both confusion over this situation and the church's desire to seek its own place in the new conditions. Until the legal regulations resulting from the constitution and the new legal order in the state were adopted, the Synod stood up to defend the existing rights that it had managed to acquire: to preserve the status of the public corporate nature of the church, to demand funding for church activities from the state coffers, and to guarantee days off on Sundays and public holidays. A new territorial division of the ecclesiastical province was also established at that time and came into force in 1921.

Two superior administrative units were established, one each for the eastern and western parts of the province. Each had the office of general superintendent whose tasks included, apart from spiritual guidance in the church, joint management of the institution defined as a consistory, headquartered in Szczecin. The territorial range

her children alone. Friedrich Albert, who inherited his father's agricultural interests, eventually decided to study theology. After graduating from the Real Middle School in Bydgoszcz (1901), having obtained a supplementary certificate from the Royal Middle School there in 1902 which confirmed his knowledge of Hebrew, Greek and Latin, was able to study theology. Onnasch was a divinity student in Heidelberg, Berlin, and Halle. The studies concluded with the first theological exam (pro venia concionandi), passed in Poznań on 7 October 1905. The decision made at that time by the candidate of theology characterized his attitude well: he wanted to prove himself seriously and responsibly in difficult pastoral work and therefore continued his service in the diaconate workshops in Bethel. He was ordained on 13 September 1907 in Poznań. Between 1909 and 1922, Onnasch led an activation colony for the unemployed and underprivileged in Lobethal near Berlin. Together with his wife Maria and four children, he came to Koszalin in 1922 to take up the position of the first pastor of the Church of St. Mary. Personal file of F.A. Onnasch, Evangelisches Zentralarchiv Berlin, file no. 14/23815.

18 A reference to: Kirchliches Amtsblatt des Königlichen Konsistoriums der Provinz Pommern (published by Buerau des Konsistoriums in Szczecin as of 1869). Since 1918, the periodical came out under the title Kirchliches Amstsblatt des Evangelischen Konsistoriums der Provinz Pommern, hereinafter referred to as KAMBP. 
of both districts showed a significant convergence with the previous influences the Pomeranian lands had been subject to for the past two hundred years. The eastern part, under Brandenburg-Prussian rule, was called Farther Pomerania (Hinterpommern). Located west of the River Oder, Hither Pomerania (Vorpommern), under the influence of Sweden until 1815, was the western part of the church province. As of 26 October 1921, the superintendent for the eastern part of Pomerania was Dr Paul Kalmus, while the city of Szczecin and the local Reformed (Calvinist) parish and the western area was entrusted to Dr Walter Kähler.

Elections to the General Synod were held in September $1921^{19}$ with the aim of adopting a program for the Church of the Prussian Union for the years to come. The earlier proposals for change included the most important issue: direct elections to parish councils. For the first time, women were to be given the right to stand for election and to vote in the church. The electoral law was to be proportional. From this point on, we can talk about a gradual democratisation of church life, although it took parishioners a considerable amount of time to become accustomed to the new form of that life.

The results of the election to the first General Synod showed a significant correlation between the political views of the voters, the social structure of the Evangelicals in Pomerania, and poor familiarity with the mechanisms of ecclesiastical democracy. ${ }^{20}$ In this way, the gradually expanded church democracy began to trickle from the top down.

In the 1920s, Koszalin (Köslin) was the second largest city east of the River Oder, after Szczecin. It was the capital of a Regierungsbezirk, a centre of agriculture and the food processing industry, and an administrative hub. The city's population was 28,000 , and the biggest parish was the Church of St. Mary. ${ }^{21}$ Seven years after Friedrich Onnasch's arrival in the capital of the Regierungsbezirk, the effects of his pastoral work were self-evident, as presented in the minutes of the General Ecclesiastical Visitation held from 3 May to 27 May 1929.22 The report depicts him as a zealous and dedicated clergyman. St. Mary's Parish was the centre of Minister Onnasch's pastoral work: the services were attended by a large number of the faithful and the superintendent's sermons were considered "thought-provoking and sensitising the conscience." 23

The parish life in Koszalin under the leadership of Friedrich Onnasch was highly varied; many of the activities lay with the parish council and lay people were responsible for them. The visitation committee considered the activities of the parish's Evangelical Self-Help Circle for Women as a model example of commitment; the Evangelische Frauenhilfe was headed by Stefanie Mackensen von Astfeld

19 [Election campaign ads] KAMBP 1921, no. 53, p. 95ff.

${ }^{20}$ [Election results] KAMBP 1921, no. 53, p. $145 \mathrm{ff}$.

${ }^{21}$ For the socio-political situation in Koszalin of the 1920s, see K. Pencarski, Dwudziestolecie międzywojenne, druga wojna światowa, [in:] Dzieje Koszalina, vol. 1: Do 1945 roku, R. Gaziński, E. Włodarczyk (eds.), Koszalin 2016, pp. 343-344.

${ }^{22}$ Evangelisches Zentralarchiv Berlin Bestand 7 Pommern, file no. 17092, "Bericht über die Generalkirchenvisitation im Kirchenkreis Köslin,” 3-27 May 1929.

${ }^{23}$ Ibidem, p. 21. 
(1894-1985). ${ }^{24}$ This organisation, in existence since the 1880s, was one of the first forms of independent activity of women in the Evangelical Church. ${ }^{25}$ Superintendent Onnasch emphasised the active role of the laity, yet, as the report following up on the visitation highlights, "the situation with male youth and adults is much worse, as political, sports and gymnastics associations take up time they could dedicate to matters of the Church." ${ }^{26}$

That same report reveals, moreover, areas of conflict and dispute within the Evangelical congregation of Koszalin in 1929. The "struggle for schools" (Schulkampf) was ongoing. Sensitivity to the presence of the church in the process of education had been a bone of contention in relations between the Evangelical Church and the state since the structural reforms of 1919. The so-called school compromise, concluded by the National Assembly in 1919, provided that with the consent of parents the creation of classes in which the religious criterion was the basic factor in the selection of students was maintained. The religious authorities had no direct control of the schools, but ultimately they had an impact on the education process via parents and religion teachers. ${ }^{27}$

A newsletter for the parishes of the church district of Koszalin was first published in $1926 .{ }^{28}$ Superintendent Onnasch's articles dealt with the general themes of church life, and drew attention to society's approach to religion and the need for the laity to work together for the church: "Two years ago (1926), we assumed that there must be one person in each village who brings the others to study the Bible together. There need not always be a priest for spiritual life to flourish. Until we have achieved this goal, it will be difficult for us to build a community of love."29

\section{Towards a difficult time - Koszalin on the eve of Nazi rule}

Like other clergymen, Friedrich Onnasch espoused strong national views. ${ }^{30}$ However, when it comes to clarity of position and opinions on controversial topics, the Koszalin superintendent expressed himself simply and bluntly: new currents and opinions

${ }^{24}$ Ibidem, pp. 7-8.

${ }^{25}$ Ibidem, p. 8.

${ }^{26}$ Ibidem, p. 9.

27 See H.G. Herlitz, W. Hopf, H. Tietze, Deutsche Schulgeschichte von 1800 bis zur Gegenwart. Eine Einführung, München 2005, pp. 117-126.

${ }^{28}$ See Gemeidendeblatt für die St. Mariengemeinde in Köslin 1926-1941, also under the titles Synodalblatt des Kirchenkreises Köslin and Gemeindeblatt Synodalblatt des Kirchenkreises Köslin, from the collection of the Universitätsbilbliothek Greifswald, file no. 570/FK 41: 8s4. Publication for the parish of Sarbinowo (Sorenbohm), see Deutsche Nationalbibliothek, Leipzig, file no. ZB 32661.

${ }^{29}$ See Gemeidendeblatt für die St. Mariengemeinde in Köslin 1928, no. 9, p. 70.

${ }^{30}$ F. Onnasch, Tagebuch [unpublished manuscript from the Onnasch family archive]. The Superintendent from Koszalin would regularly write notes he called a Journal. This term, however, is misleading, as once a year, on 31 December, Friedrich Onnasch was in the habit of making a written summary and a retrospective assessment of the year drawing to an end. The family calls this document New Year's Eve Memoir [a remark by Prof. Martin Onnasch, Friedrich Onnasch's grandson]. In the following part of the article, I quote from an unpublished source from the Onnasch family archives. Unless otherwise stated, all translations into Polish come from the author of the article. 
need not be always supported. They must be opposed when necessary, such as in the case of the so-called German Church (Deutschkirche) or measures meant to undermine the legitimacy of the use of the Old Testament in the church. Entries in the Superintendent's Journal from 1932 describe a very tense political life. The minister from Koszalin wrote that 1933 was a time "most memorable in his life so far." 1

In the early 1930s, the impact of the Nazi party in Koszalin and across Pomerania was mounting steadily. The Superintendent's Journal does not detail the dynamic of the time. We can find evidence of it in the first issue of Gemeidendeblatt für die St. Mariengemeinde in Köslin of January 1934, which published a summary report by Friedrich Onnasch. ${ }^{32}$ As in the entries of the Journal, the introduction to the account of the events of 1933 is positive. The time of divisions in the German nation was over and work for the community had begun. The support for the National Socialist vision of the state, as the Koszalin superintendent wrote, was strong, because the belief in a new beginning had restored a sense of unity. This attitude was expressed, for example, by "celebrating the first of May as a national work holiday. No one was offended, as in previous years, and we did not quarrel with one another." ${ }^{33}$ However, later developments showed that things were different, because the situation in the parish was very similar to that in other parts of Germany. Namely, groups connected with so-called German Christians (Deutsche Christen), a kind of fusion of Nazism and some Christian themes, emerged. ${ }^{34}$ The Koszalin superintendent was consistently wary of such tendencies and criticised the appropriation of parish councils by the followers of German Christians:

We pick and choose things that suit us, as if from a vending stall, and fashion them into a Nordic religion. If that's what they say, it's our duty to talk to people who espouse such views, to be

31 Ibidem, p. 71.

32 Gemeidendeblatt für die St. Mariengemeinde in Köslin 1934, no. 1, pp. 1-2.

33 Ibidem, p. 1.

34 The programme of this formation formulated in 1932 referred directly to the assumptions of the NSDAP. Demanding, among others, so-called positive Christianity, i.e. the fight against Marxism, Jews, the world's bourgeoisie and freemasonry, it proposed to undertake a radical transformation of the entire life of the church. The main goal for the dynamically developing movement was to lay "new foundations" of the church, based on the principles of racism and committed to the pursuit of the paradigm of excluding all that was not German and contrary to the adopted assumptions of "Aryanism" and racial uniqueness. The concept imposed by German Christian activists provided for the elimination of individual local churches and the adoption of a church completely subordinate to the state. Some claimed that it was even integrated with the state, which gradually came to be defined by the leader, Adolf Hitler. The contents of the programme, developed on the basis of the formation of German Christians, were presented during a mass rally at the Berlin Palace of Sport, a few months after the Nazi government took power. For many supporters of National Socialism, the programme announced in November 1933 was so revolutionary that only some of them were able to accept it: the aim was to remove all non-German elements from religious services, to restore the true essence of the Gospel message, not the one imposed by Rabbi Paul. In the following years, German Christians dominated most of the parish councils. The gradually forming opposition, clustered together within the Bekennende Kirche (Confessing Church) established in 1934, controlled the situation only in a small number of local churches, called "untouched," and their impact was very limited. See guidelines for the programme of German Christians, in: Herausgefordert. Dokumente zur Geschichte der Evangelischen Kirche in der Zeit des Nationalsozialismus, S. Hermle, J. Thierfelder (eds.), Stuttgart 2008, pp. 47-48. 
completely open with them and show where the error lies. Whenever people come to me who think in this way, I try to talk to them honestly and openly, like with any seeking person. Still, men who promote that point of view can never be the leaders of our Church. ${ }^{35}$

The Koszalin superintendent called the period between the elections to the church's bodies and their incorporation (July-October 1933) "a time of darkness and helplessness from which a way out must be found." ${ }^{\prime 6}$ The one and only answer was faithfulness, absolute faithfulness "to the LORD, who saved me, who saved me with all his life and passion, and who has risen!" 37

Thanks to the relentless efforts of the Rev. Onnasch, the Koszalin parish never accepted German Christians into decision-making bodies. ${ }^{38}$ "The group of German Christians in Koszalin was dissolved and we do not have them in the parish council." ${ }^{39}$ The absence of a group so much sought after by the ecclesiastical authorities and newly elected Bishop Thom, "an inexperienced man, whose only merit was membership in the National Socialist German Workers' Party (NSDAP), ${ }^{440}$ hampered the life of the parish. In 1933, Rev. Onnasch's doubts and concerns were more profound than his initial joy from regaining national unity:

All the parties disappeared, all the newspapers were subjected to censorship and at the end of the day wrote the same. No one was allowed to criticize anyone. This state of affairs is dangerous in the long run, both for the nation and the government. It is indeed unfortunate that the spirit of violence has also penetrated the Church [...]. I rejoiced at the onset of national elation, and now I ask myself: "Will all that is happening prove to be a blessing on our nation? ${ }^{41}$

On 4 January 1934, Reich Bishop Heinrich Müller announced a decree On restoring order within the Evangelical Church. This document, popularly known as the "muzzle," laid down disciplinary measures against clerics who used the pulpit to promote activities unrelated to the proclamation of the Gospel (lauteren Evangeliums). ${ }^{42}$ Clergymen of the Pastors in Need Association (Pfarrernotbund) published an appeal against the action of the church's supreme authorities and disseminated it all over the country. The text of the appeal was read by ministers in Koszalin on 14 January. The authorities tried to prevent the presentation of the document after religious services, trying to stall at all costs any meeting of parish councils and church groups. ${ }^{43}$

On 7 February 1934, Superintendent Onnasch, along with nine other ministers, was suspended as a clergyman by Bishop Thom and relegated from his position. ${ }^{44}$

35 Gemeidendeblatt für die St. Mariengemeinde in Köslin 1934, no. 1, pp. 1-2.

${ }^{36}$ Ibidem.

${ }^{37}$ Ibidem.

${ }^{38}$ K. Scheel, Die Bekennende Kirche in Köslin 1933-1945, n.d., p. 5, Sammlung Klän.

${ }^{39}$ F. Onnasch, Tagebuch, op. cit., p. 63.

${ }^{40}$ Ibidem, p. 71.

${ }^{41}$ Ibidem, p. 72.

${ }^{42}$ For the text of the ordinance, see: Herausgefordert, Dokumente zur Evangelischen Kirche, p. 143.

${ }_{43}$ See W. Klän, Die Evangelische Kirche Pommerns in Republik und Diktatur. Geschichte und Gestaltung einer preußischen Provinz, Geschichte und Gestaltung eine r preußischen Provinz, KölnWeimar-Wien 1995, p. 214.

44 Ibidem, p. 215. 
The parishioners staged a successful protest: a thousand people convened at the congregation and demanded a stay of disciplinary measures. ${ }^{45}$ Friedrich Onnasch resumed his duties in the parish on 1 March.

\section{Formation of theological opposition and the foundations of a "confessing parish"}

Inside the Evangelical Church in Germany, a process of consolidation of the opposition began. The initial most significant result of this was the Confessing Synod, held in Barmen-Gemarke on 29-31 May 1934. The synodal traditions of the Reformed Church, also adopted by the Evangelical Church in the nineteenth century, revived the theological and social forces within the church, which were to oppose the prevailing theological doctrine and institutional violence of German Christians. Arguments against this heresy were put forth as six theses. No political issues were raised. ${ }^{46}$ The declaration was drafted by Karl Barth (1886-1968) in collaboration with Hans Asmussen (1898-1966), Thomas Breit (1880-1966) and Hermann Sasse (1895-1976). The first, third, and fifth theses underline the absolute exclusivity of the Gospel and firmly oppose the appropriation of ecclesiastical preaching by any ideology. The declaration adopted in Barmen provided grounds for its implementation in the Evangelical Church in Germany and its individual local churches. As a consequence, a possibility arose of establishing a church which would act independently, because the incumbent ecclesiastical authority had lost its legitimacy. The singleleader system represented by the authorities of the Evangelical Church at the level of central government stood in contrast to the synod in Barmen with its collective leadership, known as a council of brethren (Bruderrat). ${ }^{47}$ In Pomerania, a brethren's council was established on 7 May 1934. The first Confessing Synod was held in Szczecin ${ }^{48}$ it was attended by clergymen from a variety of parishes from Pomerania, mainly Farther Pomerania. A group composed of representatives of clergy and laity elected Reinold von Thadden as president. On the first day of the synod, a paper titled The Church gathering under the Divine Word (Kirche unter dem Wort) was delivered by the Rev. Friedrich Onnasch, the suspended superintendent from Koszalin. New obligations were imposed on him by the changing conditions in the life of his parish. Importantly, Onnasch's actions were supported by the council: on 11 November 1934, a bold decision was made at the parish assembly and the entire Marian parish joined the Confessing Church, to remain there until 1945. ${ }^{49}$ Entries from 1934 in the minister's Journal confirm the zeal and tense commitment: "We got down to work,

${ }^{45}$ K. Scheel, Die Bekennende Kirche..., op. cit., p. 5.

${ }^{46}$ G. Niemöller, Die erste Bekenntnissynode der Deutschen Evangelischen Kirche zu Barmen, vol: Geschichte, Kritik und Bedeutung der Synode und ihrer Theologischen Erklärung, Göttingen 1959, pp. 7-10.

${ }^{47}$ Ibidem, p. 16.

${ }^{48}$ See W. Klän, Die Evangelische Kirche Pommerns..., op. cit., p. 247.

${ }^{49}$ K. Scheel, Die Bekennende Kirche..., op. cit. 
forming a confessional community. Without much publicity, about nine hundred people joined us. During the meetings the room was always full of people. ${ }^{\prime 50}$ Karl Scheel observes that the meetings of the Confessing Congregation were regularly attended by approximately 1,500 faithful, half of whom paid the dues. ${ }^{51}$

The activity of the parish in Koszalin is a unique example of the involvement of the laity in church matters, unusual in Nazi Germany. The operation of the Marian Parish involved cooperation between clergy and laity. Regular bi-weekly biblical meetings were held in small groups and starting in 1935 conventions for the laity were convened every two months. They integrated people actively involved in the life of the parish. The topics raised included issues such as Christian upbringing, confirmation and the family. Taking into account the totalitarian nature of the Nazi state, which did not condone any competition in modelling reality, the pastoral agenda of the parish in Koszalin is an example of ecclesiastical work aimed at overcoming the appropriation of the church by the regime's supporters. Superintendent Onnasch's actions were directed, as he himself wrote, at fulfilling the Reformation demand of a priesthood of all the faithful: "We must take the cause of the laity seriously in the Evangelical Church on account of the priesthood of all the faithful. Therefore, in the parish of Köslin, we have established Bible study groups, which are not led by theologians, but by lay people." 52 Such a mode of operation proved to be very useful, as the state's attacks on the church and the clergy were intensifying. After the Dahlem Synod, held between 19 and 20 October 1934, independent structures of the Confessing Church began to emerge. In the long run, this would mean the creation of an independent church and the dissolution of the existing forms of administration. The Nazi state would not tolerate such developments. A new ministry for the confessions was established in order to organize the Evangelical affairs of the church, and the persecution began. In Rev. Onnasch's Journal we can find reminiscences of that time: "Many priests of the Confessing Church went to concentration camps. Some of them were arrested and pre-emptively detained." ${ }^{53}$ According to the data of minister Karl Scheel, four clergymen were put in prison in $1937 .{ }^{54}$

\section{Confessing preaching seminars in Western Pomerania}

The independence of the Confessing Church meant its exclusion from official structures along with all the consequences: access to church buildings was limited and the clergy did not receive salaries. The only means of self-financing was money raised among the parishioners. Each of these components was indispensable for the

${ }^{50}$ F. Onnasch, Tagebuch, op. cit., p. 63.

${ }^{51}$ K. Scheel, Die Bekennende Kirche..., op. cit.

${ }_{52}$ See Gemeidendeblatt für die St. Mariengemeinde in Köslin 1936, year 11, no. 12-13.

${ }_{53}$ F. Onnasch, Tagebuch, op. cit., pp. 78, 81.

${ }^{54}$ K. Scheel, Die Bekennende Kirche..., op. cit., p. 10. These were among others Minister Paulus Büttner from Strzępów (Strippow), Werner Grude from Zegrze Pomorskie (Seeger) and Gerhard Friedrich from Koszalin (preaching station in Luther's House). 
development of communities. Amidst mounting terror and growing tensions within the Confessing Church, its survival depended on the generosity of those who identified themselves with the theology of the ministers.

In the structures of the Confessing Church, which operated within the framework of the Church of the Old Prussian Union, several homiletical and formative seminars were established in Bielefeld, Düsseldorf, Naumburg am Queis, and other places. One was opened in Zdroje n. Szczecin (Finkenwalde) and was led by Dietrich Bonhoeffer (1906-1945). The Gestapo dissolved this illegal course on 28 September 1937. ${ }^{55}$ Further theological education in even more difficult conditions took place in so-called collective vicariates. It was a different form of work than in Zdroje, because a decision was made to assign candidates to the vicariate to specific ministers who belonged to the Confessing Church or worked closely with it. Candidates for work in these extremely difficult conditions lived in their parishes. The courses were organized in the parishes in Koszalin and Słonowice (Groß-Schlönwitz) simultaneously, with most of the participants not coming from Pomerania. ${ }^{56}$ The first edition took place in the winter of 1937-1938, and the last in the winter of 1939-1940 in Słonowice. ${ }^{57}$ This unique form of community life, practiced by the seminarians in Zdroje, developed and gained depth precisely in Western Pomerania. ${ }^{58}$ Słonowice was entrusted to Superintendent Eduard Block (1886-1970). ${ }^{59}$ Most of the ministers in his ecclesiastical district belonged to the Confessing Church and therefore organisation of internships for the vicariate was not difficult. In Koszalin there was a duo of theologians, Friedrich Onnasch Sr. and his eldest son Friedrich, called Fritz. Friedrich Onnasch, Jr. (1911-1945) was himself a graduate of the Finkenwalde course, and as an inspector of courses in Koszalin was in charge of all the work there. ${ }^{60}$ Ultimately, this form of education ended in the winter of 1940, when theology students and clergymen were drafted into the army.

In 1938 came another test for the Confessing Church under the Reich: on 20 April, all active clergymen were ordered to take an oath of allegiance to Hitler. ${ }^{61}$ The initial protest from the Confessing Church Synod ultimately proved to be no avail. Most clergy, including Friedrich Onnasch, took an oath of allegiance to Adolf Hitler. In his personal file there is a relevant document with a form attached, used

${ }_{55}$ See D. Bonhoeffer, Werke, vol. 15, Illegale Theolgenausbildung, Sammelvikariate 1937-1940, D. Schulz (ed.), Gütersloh 1998.

${ }^{56}$ For the list of candidates of the individual courses, see ibidem, pp. 614-616.

${ }^{57}$ See E. Block (Jr.), Kirchenkampf in Schlawe, [in:] Der Kreis Schlawe: Ein pommersches Heimatbuch, vol. 1: Der Kreis als Ganzes, Husum 1986, pp. 332-335.

${ }^{58}$ G. Quer, Dietrich Bonhoeffer und die theologische Ausbildung der Bekennenden Kirche in Hinterpommern, [in:] ibidem, pp. 336-341.

${ }^{59}$ Ibidem, p. 337.

${ }^{60}$ For a detailed biography of F. Onnasch Jr. see F. Bartels, Einer mit dem großen Namen, Bruder. Zum Gedenken an Friedrich (Fritz) Onnasch (1911-1945), "Zeitgeschichte Regional. Mitteilungen aus Mecklenburg Vorpommern" 2005, no. 1, pp. 78-89.

${ }^{61}$ See Herausgefordert, Dokumente zur Geschichte der..., op. cit., p. 446. 
within the Confessing Church, that "this oath must not incite anyone to violate God's commandments." 62

In his notes from 1938, Friedrich Onnasch Sr. does not mention the oath, as he believed the events he had witnessed were more important: the events of November 1938, the Jewish pogroms and the destruction of synagogues: "These are things that our people must be ashamed of! These are ways that can be described in one word: a crime. Woe to us if the seed sown that year rises." 63

Consistent rejection of any cooperation with the Nazis by some representatives of the Confessing Church led to the emergence of a position dubbed a "Pomeranian middle way." It was a compromise attitude, because approximately $90 \%$ of the Evangelical clergy of the province, which was trying to operate within the reality of the Nazi state, supported to a large extent the theological program of the Confessing Church but did not share the political attitude of the radicals, who demanded full independence from the regime. ${ }^{64}$ The loss of independence of all associations run by Evangelical parishes and the merciless practice of NSDAP activists made the Christian Churches easy prey and subjected them to total control. The composition of the parish council, formed exclusively by members of the Confessional Church, made the parish of Koszalin unique. In February 1939, Minister Onnasch became president of the Fraternal Council of the Confessing Church of All Pomerania. The group included those few who decided to follow the path set out in the Synods of Barmen and Dahlem. Apart from Onnasch, the group included Rainer von Thadden-Trieglaff and Professor Heinrich Rendtorff. Three committees were also set up to support the council proper. This is how the superintendent from Koszalin briefly accounted for the divergence of paths in the Confessing Church:

The Confessing Church is in a precarious position. It is persecuted by all, both the Ministry of Religious Affairs and the Supreme Council of the Church. In Pomerania, the issue was whether the junior brothers will take church exams in consistory (path B) or not (path A). I had to take over the leadership of the council. It is a heavy burden; may the Lord give us wisdom to know His way and will, and may He strengthen us to follow it. The work is difficult because many of the brethren have been conscripted into the army. The generosity of the donors is dwindling and we have no money to pay salaries. God himself knows how things will proceed. ${ }^{65}$

Immediately after the war started, on 9 September 1939, Friedrich Onnasch was once again arrested. The reason for his arrest was his sermon delivered on 27 August and a prayer for the clergy in concentration camps. The Gestapo arrest took place under complicated circumstances; as early as in April 1939, Minister Onnasch was drafted into the army as a military and hospital chaplain in Koszalin. After the intervention of the authorities, who would not accept a politically suspicious chaplain, the Gestapo incarcerated the minister in solitary confinement for ten days. ${ }^{66}$

\footnotetext{
${ }^{62}$ Personal file of F.A. Onnasch, op. cit., file no. 14/23815.

${ }^{63}$ F. Onnasch, Tagebuch, op. cit., p. 83.

${ }^{64}$ See H.G. Leder: Pommern, [in:] Theologische Realenzyklopädie, vol. 27, Berlin 1997, pp. 50-51.

${ }^{65}$ F. Onnasch, Tagebuch, op. cit., p. 83.

${ }^{66}$ Ibidem, p. 85.
} 
Measures against the Koszalin superintendent were gaining momentum. At the same time, during his stay in prison, the leader of the Pomeranian Confessing Church began to put more pressure on parents not to send their children to confirmation education classes. Ever new attempts were taken to introduce another clergyman, connected with the German Christians, as the minister of the Parish of St. Mary in Koszalin. Friedrich Onnasch noted in his journal: "the fight continues." ${ }^{97}$ The minister in question was Gustav Schwalm, who against the protests of the parish council became the administrator of the parish in August 1940. Superintendent Onnasch could not prevent this, as he was banned from living in Pomerania and conducting any pastoral activities in the parish. On 12 September 1940, the Gestapo had Onnasch leave with immediate effect. His wife remained on the spot to serve the parish. Maria Onnasch took over much of her husband's duties: "I prepared for her the biblical hours on the book of Job, wrote the meditations and sermons that were preached in the parish. The laymen did it. [Maria] was in touch with the brothers [of the Confessing Church]." ${ }^{68}$

One year after Onnasch was removed from Pomerania with the consent of the Reich Security Head Office, he was ordered to go to Barlinek (Berlinchen) to become a substitute minister. ${ }^{69} \mathrm{He}$ could visit Koszalin rarely, and only with a special pass. Onnasch quickly adjusted to the new workplace and the parishioners again filled the church pews, like in Koszalin. The eldest son of the Onnaschs remained in Koszalin. As a substitute for his father, but in constant contact with him, Fritz Onnasch devoted himself entirely to the work of the marginalized Confessing Church. ${ }^{70}$ Friedrich Onnasch's last journal entries were written on 31 December 1944. The minister detailed his family's situation and devoted much attention to analysis of the warfare: "Germany resembles a desert. [...] The war is shrinking. What will the new year bring? I'm afraid to ask. The government is still talking about victory. Some believe it. May God graciously help us." ${ }^{\text {"71 }}$ Church life continued despite the approaching front.

This apparent normality of wartime life was interrupted by the entry of the 12th Armoured Corps of the Red Army into Barlinek on 31 January 1945. For the next two weeks the Reverend Onnasch tried to help the local parishioners. He died, according to Karl Scheel, shot dead by the plundering Soviet soldiers on 17 February 1945.

\footnotetext{
${ }^{67}$ Ibidem.

${ }^{68}$ Ibidem.

${ }^{69}$ Ibidem, p. 95.

${ }^{70}$ W. Klän, Die Evangelische Kirche..., op. cit., pp. 580-581.

${ }^{71}$ Ibidem, p. 102.
} 


\section{“The Indomitable from Pomerania" - a remembrance ${ }^{72}$}

Reminiscing on his youth, the author Klaus Hupp ${ }^{73}$ described how, as a young man of eighteen, together with his brother Gerhard, he walked out of the Church of St. Mary in Koszalin, adorned for the feast of Nativity, on Christmas Eve of 1939. The war was on. At that time, Superintendent Friedrich Onnasch stood at the pulpit and quoted in a loud voice the words from the Gospel according to John (Jn 8:12): "This is the word of the Lord' ${ }^{74}$ : I am the light of the world. Whoever follows me will not walk in darkness but will have the light of life." The young, energetic and proud youngsters did not expect anything from the church as all the needs of their souls were satisfied by the winter solstice festival offered by the Hitlerjugend. ${ }^{75}$ In his sermon, the Rev. Onnasch criticised the pagan rituals and reminded the youth about their obligations towards the church. Many years later, recalling his Koszalin times, Hupp was able to assess the situation that night: "We were going home in silence. Much later I became aware of the reasons why Onnasch was often said to be in prison. All of his services were attended by secret police, the Gestapo. That night they were there too; they were sitting in front of us." 76

It took many years for successive generations to discover the importance of the legacy left by the Confessing Church in the history of Christianity. The memory of the Rev. Onnasch's activities remains part of the cultural depository of the German Evangelicals who left Pomerania in 1945. However, its value for building mutual Polish-German relations has also been discovered by today's inhabitants of the city. In 2004, at the request of the historians of the region and the Evangelical Lutheran Parish in Koszalin, the Koszalin Socio-Cultural Society took the initiative to unveil a plaque in honour of Superintendent Friedrich Onnasch and his son, Friedrich Junior, involved in the struggle against Nazism.

Therefore, the twentieth-century history of Koszalin is incomplete without references to those difficult times. Research into the extraordinary past of the Evangelical Parish of St. Mary, today the seat of the Roman Catholic Bishop of the Diocese of Koszalin and Kołobrzeg, is an example of the development of historical religious studies in Poland.

72 The title of a radio broadcast of Polskie Radio Koszalin, 7 October 2004.

${ }^{73}$ Klaus Hupp (1921-2001), an author of numerous books on the history of education, memoirs on Pomerania, e.g. My Youth in Koszalin (Meine Jugend in Köslin), Husum 1994.

${ }^{74}$ Ibidem, p. 57.

75 Ibidem, p. 58.

${ }^{76}$ Ibidem, p. 63. 


\section{Bibliography}

500 lat Reformacji w Polsce, available at: http://www.stat.gov.pl [access: 20.06.2020].

Barnett V., For the Soul of the People. Protestant Protest Against Hitler, New York-Oxford 1992.

Bartels F., Einer mit dem großen Namen, Bruder. Zum Gedenken an Friedrich (Fritz) Onnasch (1911-1945), "Zeitgeschichte Regional. Mitteilungen aus Mecklenburg Vorpommern" 2005, no. 1, pp.78-89.

Bergen L., Twisted Cross. The German Christian Movement in the Third Reich, Chapel Hill 1996.

Bericht über die Generalkirchenvisitation im Kirchenkreis Köslin, vom 3 bis 27 Mai 1929, Evangelisches Zentralarchiv Berlin Bestand 7 Pommern, sygn. 17092.

Block E., (Jr.), Kirchenkampf in Schlawe, [in:] Der Kreis Schlawe: Ein pommersches Heimatbuch, vol. 1. Der Kreis als Ganzes, Husum 1986, pp. 332-335.

Bonhoeffer D., Werke Bd.15, Illegale Theologenausbildung, Sammelvikariate 1937-1940, hrsg von D. Schulz, Gütersloh 1998.

Borzyszkowski J. (ed.), Nekropolie Pomorza, Gdańsk 2011.

Czermińska M., Poruszona przestrzeń (świadectwa wędrówek ludów po traktacie jałtańskim), [in:] eadem, Autobiograficzny trójkąt. Świadectwo, wyznanie i wezwanie, Kraków 2000, pp. 159-176.

Gadacz T., Milerski B. (eds.), Religia. Encyklopedia PWN, vol. 3, Warszawa 2001.

Gaziński R., Włodarczyk E, (eds.), Dzieje Koszalina, vol. 1: Do 1945 roku, Koszalin 2016.

Gemeidendeblatt für die St. Mariengemeinde in Köslin, Köslin 1926-1941.

Giedrojć M., Mieszkowski J. (eds.), Pomerania ethnica. Mniejszości narodowe na Pomorzu Zachodnim, Szczecin 1998.

Herlitz H.G., Hopf W., Tietze H., Deutsche Schulgeschichte von 1800 bis zur Gegenwart. Eine Einführung, München 2005.

Hermle S., Thierfelder J., Herausgefordert. Dokumente zur Geschichte der Evangelischen Kirche in der Zeit des Nationalsozialismus, Stuttgart 2008.

Heyden H., Kirchengeschichte Pommerns, Stettin 1937.

Hupp K., Meine Jugend in Köslin, Husum 1994.

Jackowski A., Święta przestrzeń świata. Podstawy geografii religii, Kraków 2003.

Jankowiak S., Ziemie Zachodnie i Pótnocne w stosunkach państwo-Kościół w Polsce w latach 1945-1956, [in:] Między integracją a komunizmem. Społeczeństwa i kościoły Europy Środkowej. Materiały z międzynarodowej konferencji naukowej, Szczecin, 8-9 czerwca 2001 r., K. Kowalczyk, A. Kubaj, R. Wróblewski (eds.), Tuchów 2001, pp. 88-96.

Klän W., Die Evangelische Kirche Pommerns in Republik und Diktatur. Geschichte und Gestaltung einer preußischen Provinz, Geschichte und Gestaltung eine r preußischen Provinz, Köln-Weimar-Wien 1995.

Kłaczkow J., Kościót Ewangelicko-Augsburski w Polsce w latach 1945-1989, [in:] idem, Kościoty luterańskie na ziemiach polskich (XVI-XX w), vol. 3: W ramach Rzeczpospolitej, państw ościennych i na emigracji, J. Kłaczkow (ed.), Torun 2012.

Kuszyk K., Poniemieckie, Wołowiec 2019.

Leder H.G, Pommern, [in:] Theologische Realenzyklopädie, vol. 27, Berlin 1997, pp. 50-51.

Matelski D., Niemcy w Polsce w XX wieku, Warszawa-Poznań 1999.

Niemöller G., Die erste Bekenntnissynode der Deutschen Evangelischen Kirche zu Barmen, vol. 1: Geschichte, Kritik und Bedeutung der Synode und ihrer Theologischen Erklärung, Göttingen 1959.

Onnasch F., Tagebuch [unpublished manuscript from the Onnasch family archive].

Onnasch F., Personalakte, Evangelisches Zentralarchiv Berlin, sygn. 14/23815.

Romanow Z., Kreowanie "polityki pamięci” na Pomorzu Zachodnim 1945-2000, Poznań 2002.

Siedziako M., Stanuch Z., ks. Wejman G., (eds.), Dzieje Kościoła rzymskokatolickiego na Pomorzu Zachodnim, vol. 1: 1945-1956, Szczecin 2016. 
Scheel K., Die Bekennende Kirche in Köslin 1933-1945, n.d.

Sławek T., Akro/nekro/polis. Wyobrażenia miejskiej przestrzeni, [in:] Pisanie miasta - czytanie miasta, A. Zeidler-Janiszewska (ed.), Poznań 1997, pp. 29-31.

Wierzchosławski D., Ludność Ziem Zachodnich i Północnych w świetle Narodowego Spisu Powszechnego 2002, [in:] Ziemie Odzyskane. Ziemie Zachodnie i Pótnocne 1945-2005. 60 lat w granicach państwa polskiego, A. Sakson (ed.), Poznań 2006, pp. 79-80. 